\title{
Microbiological Quality Evaluation of Various Types Of Traditional Romanian Cheese Through Advanced Methods
}

\author{
Alexandra TĂBĂRAN ${ }^{1}$, Sorin Daniel DAN ${ }^{1 *}$, Oana REGET ${ }^{1}$, Darius Victor CORDEA ${ }^{1}$ Alina MĂGDAŞ ${ }^{2}$, \\ Marian MIHAIU ${ }^{1}$ \\ ${ }^{1}$ Department of Animal Production and Food Safety, University of Agricultural Sciences and Veterinary \\ Medicine, Faculty of Veterinary Medicine, 3-5 Mănăştur Street, 400372, Cluj Napoca, Romania \\ ${ }^{2}$ National Institute for Research and Development of Isotopic and Molecular Technologies, \\ Cluj Napoca, Romania \\ sorin_dan_daniel@yahoo.com
}

Bulletin UASVM Veterinary Medicine 73(2) / 2016,

Print ISSN 1843-5270; Electronic ISSN 1843-5378

DOI:10.15835/buasvmcn-vm: 12321

\begin{abstract}
Raw milk represents a nutritive environment for a number of pathogens, like Salmonella spp., Escherichia coli 0157: H7, Staphylococcus aureus etc. This fact can cause a serious of foodborne outbreaks associated to the consumption of contaminated milk and derivate products. The traditional processing of raw milk in poor hygiene conditions can pose a serious microbiological risk. The study aimed at evaluating the incidence of pathogen bacteria in ripened traditional cheese by advanced biochemical and molecular methods in order to reveal the possible risk of consumer exposure. The study was applied on 150 samples of ripened cheese from the following types: salted teleme cheese and „Burduf” cheese and „Năsal” cheese. The traditional teleme cheese presented an average value of the total $E$. coli count in between $11.06 \pm 0.52-38.33 \pm 2.76 \mathrm{CFU} / \mathrm{g}$. The risk represented by the presence of $E$. coli and Staphylococcus aureus is low within the first steps of ripening, being absent after 28 months of ripening in the teleme cheese samples. The Staphylococcus aureus load was in between $3.82 \pm 0.12 \log \mathrm{CFU} / \mathrm{g}$ for the first period of ripening in „Burduf” cheese and $0.27 \pm 0.56 \log \mathrm{CFU} / \mathrm{g}$ after the second period of maturation, following a descendant pathway towards the last period of ripening. In „Năsal” cheese we isolated the specific Brevibacterium linens, which gives the characteristics of this type of cheese, but also Micrococcus spp., in 35\% and lactic streptococci in 20\%. The traditional cheese evaluated represent a low risk of contamination given that no sample investigated has exceeded the maximum limits allowed by the legislation and no pathogen bacteria isolated.
\end{abstract}

Keywords: traditional Romanian cheese, milk, hygienic quality, PCR

\section{INTRODUCTION}

Consumer's demand for safer and higher quality food products is continuously growing on a global scale. For this reason, quality management systems have been developed, so as to monitor constantly the hazard occurrence and prevent possible outbreaks (Sandrou and Arvanitoyannis, 2000). The most dangerous and severe hazards occurring daily in animal origin products such as cheese are the biological ones (Tranter, 1990), the dairy industry increasing constantly the efforts to ensure the quality and safety through the development and implementation of proactive programs such as the HACCP (Ito, 1974).

Cheeses are the most popular dairy products in the entire world, processed under various types and shapes according to country and traditionality (Fox et al., 2000). The world cheese production 
has increased, with an annual rate of $4.2 \%$ during the last 20 years (FDA, 2001). Researches concerning the food poisoning cases caused by contaminated cheese consumption show that the scarces processing conditions contributes the most to the development of the causative agent (FDA, 2001). Normally when such episodes occur a large number of people are affected. Thus, the application of a strict surveillance within cheese production line can minimize the risk of foodborne illnesses occurrence (Hill, 2000, Temelli et al., 2006).

Unfortunately, the traditional processing of cheese does not comprise these strict surveillance systems, which sometimes make it very difficult to control the occurrence of pathogens. These types of products are a very nutritive environment for numerous pathogens such as Salmonella spp., Escherichia coli 0157:H7, Staphylococcus aureus etc. The traditional processing can represent a higher risk of contamination due to poorer hygiene conditions and lack of strict surveillance system. Until now there have been a serious of foodborne infection episodes stated to be caused by consumption of contaminated cheese with Salmonella, Campylobacter, Staphylococcus aureus and E. coli 0157: H7 (Zottola and Smith, 1991; De Buyser et al., 2001). The aim of this study was to evaluate the incidence of pathogens in ripened cheese obtained in industrial and traditional systems with an emphasis on the risk exposure assessment.

\section{MATERIALS AND METHODS}

Sample collection and preparation

The material subjected to research was represented by 150 of ripened telemea cheese products obtained in the industrial system and salted "telemea" cheese obtained in a traditional system. All the samples collected were kept in their original package and kept at $0 \ldots 4^{\circ} \mathrm{C}$ until their further analysis. The analysis was made within 48 hours from their reception in the Food safety laboratory of Faculty of Veterinary Medicine Cluj Napoca.

\section{Identification of Staphylococcus spp.}

The isolation and identification of Staphilococcus spp. was made according to the current standard protocol (SR EN 6888/2005). Briefly, the specific solid media used was Baird - Parker (Oxoid; Germania) and the incubation made at $37^{\circ} \mathrm{C}$ for 24 hours. The confirmation was made by cultural examination, evaluating the colonies' aspect on the selective media (color, size, shape, aspect and margins) and morphological exam (Gram staining). The representative colonies were subjected to polymerase chain reaction (PCR) confirmation technique.

\section{Identification of $E$. coli}

The isolation and identification of $E$. coli was made according to the protocol described in the current standard (SR EN 16649-2/2007). Briefly, the solid culture media used was TBX (Triptone Bile X-Gluconoride) (Oxoid; Germania). The incubation was made at $37^{\circ} \mathrm{C}$ for 24 hours and the confirmation followed the same protocol as for Staphylococcus spp., described in detail above.

PCR method for bacteria genera confirmation

The DNA extraction was made from morphologically confirmed E. coli colonies. The DNA was extracted from approximately 10-12 specific colonies using a specific extraction kit (Isolate II DNA kit, Bioline, Germania) following the protocol described by the producer.

The DNA quantities and purities were evaluated by spectrophotometry, using a Nanodrop ND-1000 apparatus (NanoDrop Technologies, Inc., Wilmington, DE, USA). Each sample was brought to a concentration of $20 \mathrm{ng} / \mu \mathrm{l}$ with elution buffer. The PCR technique was made in a final volume of 25

Tab. 1. The primers used for the confirmation of the isolated E.coli and Staphylococcus strains

\begin{tabular}{ccccc}
\hline Gene & Primer sequences $\left(5^{\prime}-3^{\prime}\right)$ & Size $(\mathrm{bp})$ & $\mathrm{T}\left({ }^{\circ} \mathrm{C}\right)$ & Reference \\
\hline $23 S$ & $\begin{array}{l}\text { F: AAGGAATCACCTTGCAGATAAACTC } \\
\text { R: TTTCCGAGTACATTGGCATCGT }\end{array}$ & 736 & 56 & $\begin{array}{c}\text { Malorny } \text { et } \\
\text { al., 2004 }\end{array}$ \\
\hline NUC2 & $\begin{array}{l}\text { F: ATGAAGTCAAATAAATCGCT } \\
\text { R: TTTGGTGAAAAATACTTCTC }\end{array}$ & 458 & 58 & $\begin{array}{c}\text { Gandra } \text { et } \\
\text { al., } 2011\end{array}$ \\
\hline
\end{tabular}


$\mu \mathrm{L}$, using the following reagents: MyTaq (Bioline, England) polymerase mix $(12.5 \mu \mathrm{L} /$ sample $)$ and $1 \mu \mathrm{L}$ of Forward/ Reverse Primer specific for each bacteria (Tabel no.1). The amplification was made in a G-Storm thermalcycler (LabTech, England), using 35 temperature cycles as it follows: denaturation $94^{\circ} \mathrm{C}$ (1 min.), alignment temperature according to specific primers (table 1 ) and elongation at $72{ }^{\circ} \mathrm{C}(1 \mathrm{~min}$.). The migration of the amplified products was made in an agarose gel of $2.5 \%$ concentration stained with EvaGreen DNA dye $(1.7 \mu \mathrm{l}-35 \mathrm{ml} /$ gel; $7 \mu \mathrm{l}-140 \mathrm{ml} /$ gel $)$. The electrophoresis was made at $100 \mathrm{~V}$ (20 min.) and $70 \mathrm{~V}(40 \mathrm{~min})$. The reading and interpretation was made in a Trans UV imaging system (BioRad, Germany).

\section{Statistical interpretation}

Statistical interpretation of data was performed using the operating system Windows 2007, program Origin 8.5.

\section{RESULTS AND DISCUSSION}

The results obtained at the bacterial load analysis of telemea cheese obtained in an industrial system

Due to the fact that this type of cheese is practically always covered in brine, it is protected on the surface against bacteria. E. coli and Staphylococcus aureus are pathogens with high risk on the public health.
For the safety of the telemea cheese sent for consumption it is mandatory to perform analysis on the milk destined for processing (Donnelly, 2004). In conformity with the regulations (Reg. CE 2073/2005, modified by Reg. CE 1441/2007), in case of ripened cheese subjected to thermal treatment, it is mandatory to identify the presence of staphylococci enterotoxin, the E. coli load and the number of staphylococci coagulase-positive. Regarding the presence of $E$. coli, we have found in the analyzed samples that only 2 were negative (Fig.1) (samples 7, 14), respectively 7.69\%. The rest of the samples have shown an average number in between $8.66 \pm 1.52-16.33 \pm 7.76 \mathrm{CFU} / \mathrm{g}$, values relatively low, which are in accordance with the legislation (Reg. 1441 CE/2007), of maximum 100 $\mathrm{CFU} / \mathrm{g}$. Similar values have been obtained by Suler et al. (2010), the study mentioning also that the presence of $E$. coli in this type of dairy products is due mainly to poor hygiene conditions along the technological process.

In what concerns the Staphylococcus genus, the frequency of positive samples was much lower, 8 samples being negative (20.51\%).

The statistics showed an average value of the positive samples in between $1 \pm 1.73$ and $45.66 \pm 6.02 \mathrm{CFU} / \mathrm{g}$, values that are in conformity with the legislation (max.100 CFU/g) (Fig.2). Given the fact that the coagulase-positive staphylococci load was in between the maximum limit imposed

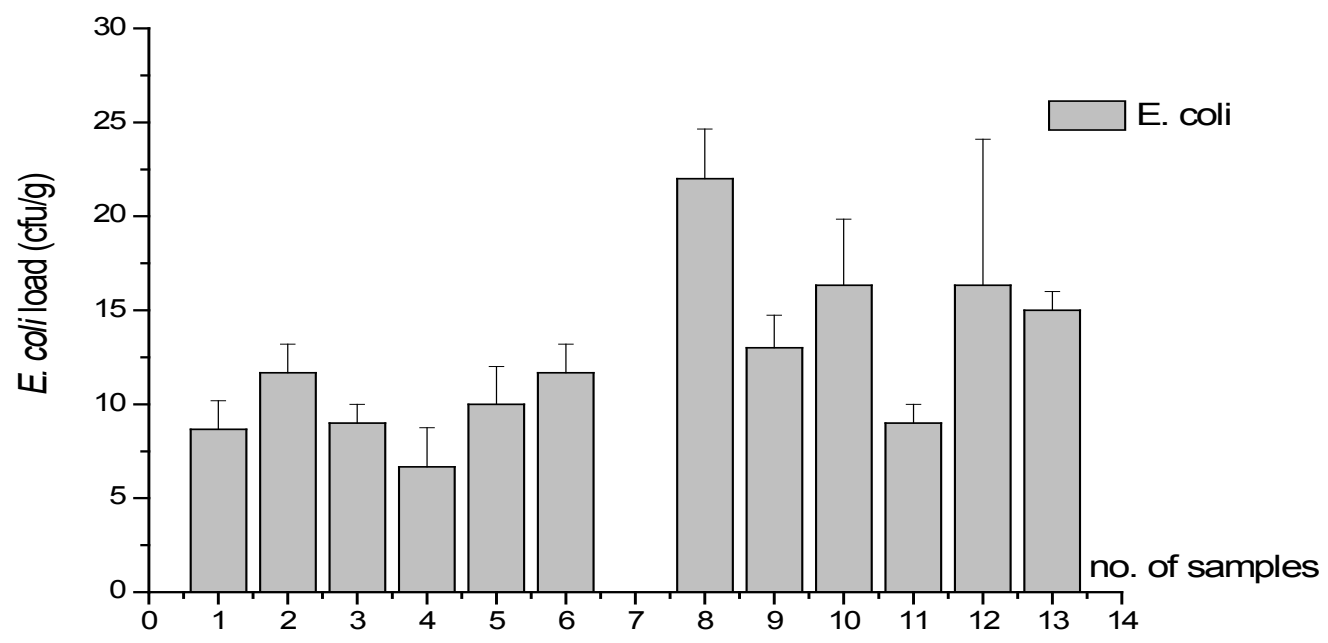

Fig.1. The representation of $E$. coli contamination of the teleme cheese obtained in the industrial system 
by the legislation (Reg. 1441 (CE)/2007), we did not test the samples for staphylococci enterotoxin. Similar values were reported by Suler et al. (2010), highlightening values in between 0.48 and $7.08 \mathrm{CFU} / \mathrm{g}$ at the same type of dairy products. In contrast, a study made by Duminică (2009), has shown that the ripened telemea cheese holds a high prevalence percent for E. coli $56.57 \%$ and average for Staphylococcus (11.76\%).

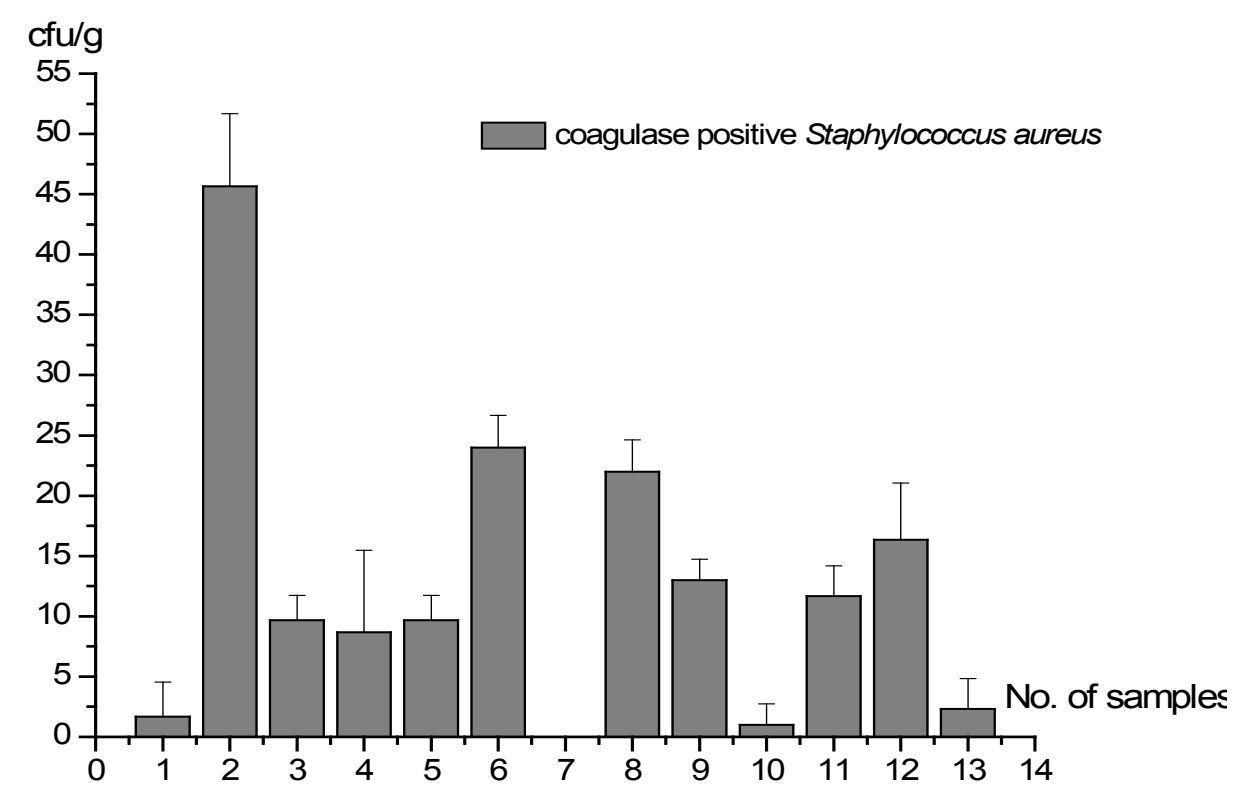

Fig. 2. The representation of the contamination with coagulase-positive staphylococci in the teleme cheese obtained in the industrial system

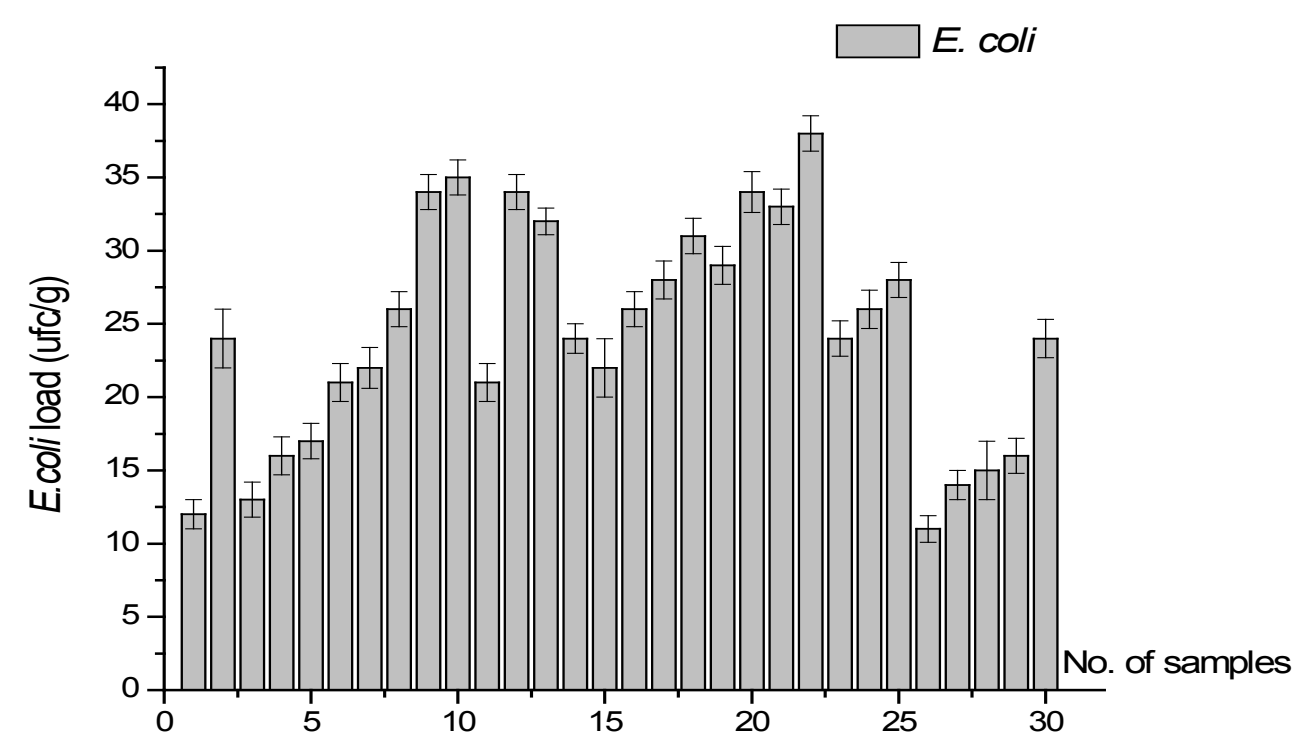

Fig. 3. The representation of $E$. coli contamination in the teleme cheese obtained in a traditional system 
A number of studies have shown high variation within the load of these bacteria according to the ripening stage. For example, Mojsova et al. (2009), has shown that in the fourth day of ripening, the average value of $E$. coli colonies is of $5.3 \log \mathrm{CFU} / \mathrm{g}$ $(200.000 \mathrm{CFU} / \mathrm{g})$, and in the tenth day the value is situated in between 2 and $4.77 \log \mathrm{CFU} / \mathrm{g}$. After 90 days of ripening, no bacteria was identified which reveals that the low value of the $\mathrm{pH}$ has inhibit the presence of these germs.

The results obtained at the bacterial load analysis of telemea cheese obtained in a traditional system

Regarding the presence of $E$. coli in traditional telemea cheese we found that no sample had a lower value than $10 \mathrm{CFU} / \mathrm{g}$. All samples have shown an average value of the total number of

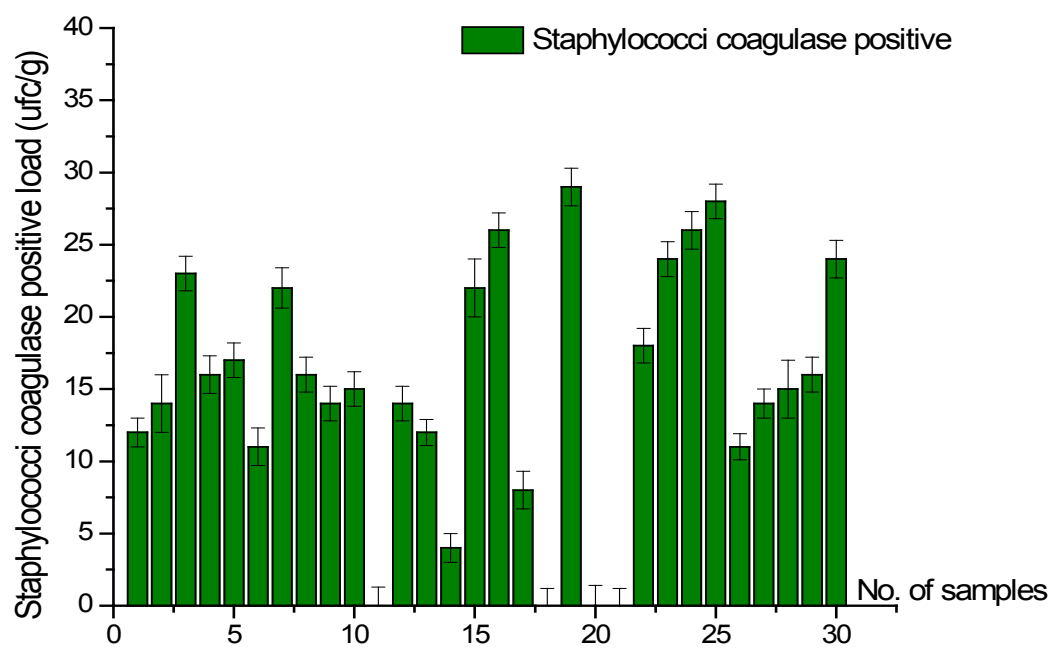

Fig. 4. The representation of contamination with coagulase-positive staphylococci in the teleme cheese obtained in a traditional system

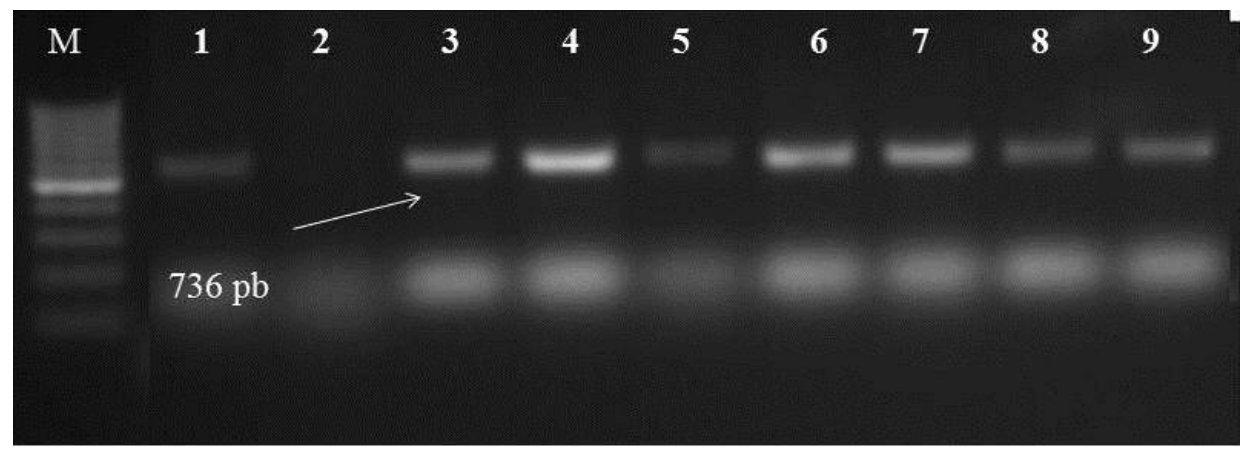

Fig. 5. Molecular confirmation of E. coli strains isolated from the industrial system „teleme” cheese; $\mathrm{M}$ - ethalon scale (100 bp); 1 - positive control; 2 - negative control; 3 - 9 - positive PCR confirmed samples

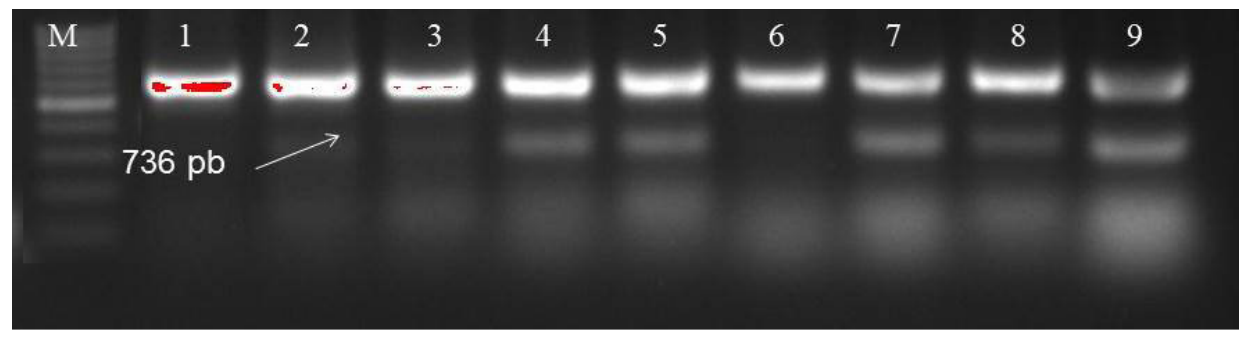

Fig. 6. The molecular confirmation of the E. coli strains isolated from the traditional teleme cheese; $\mathrm{M}$ - the ethalon scale (100 bp); 1 - positive control; 2-9 confirmed positive samples 
colonies in between $11.06 \pm 0.52$ and $38.33 \pm 2.76$ $\mathrm{CFU} / \mathrm{g}$, values that are higher than those revealed at the samples collected from the hypermarkets (fig 3).

The high load of $E$. coli in traditional telemea cheese can be attributed to the fact that this type of dairy product is normally processed from raw milk and the technological manufacturing lacks the hygiene conditions.

The Staphylococcus showed a lower prevalence, 4 samples being negative. Although the number of negative samples was higher than in $E$. coli case compared to the industrial type of telemea cheese the percentage of negative samples was much lower (13.33\% vs. $20.51 \%)$. The statistical evaluation has shown an average of Staphylococcus load in between $4 \pm 1.73$ and $23.12 \pm 2.02 \mathrm{CFU} / \mathrm{g}$, values that are in conformity with the legislation (max. $100 \mathrm{CFU} / \mathrm{g}$ ) (Fig. 4). The values obtained in our study were much higher than those reported by Suler et al. (2010), which revealed numbers in between 0.48 and $7.08 \mathrm{ufc} / \mathrm{g}$.

The molecular testing of $\boldsymbol{E}$. coli and Staphylococcus strains isolated from telemea cheese

The strains of E. coli and Staphylococcus isolated from the ripened cheese samples were molecularly tested for confirmation

All E. coli isolated were confirmed also by PCR, being positive at the specific DNA amplification with the common sequence (fig. 5, 6). The PCR protocol tested in this study was implied the identification of the common sequences for E. coli, sequence 23S, which has a molecular weight of 736 base pairs.

From the total of 43 ripened telemea cheeses, E. coli was confirmed by PCR in 42 samples. This high prevalence $(97.57 \%)$ is concerning given that other data from field literature states a lower prevalence. For example, Soomro et al. (2002) have only 57\%, and Farzan et al. (2012), $30.28 \%$. A similar percent to our was revealed by Paneto et al. (2007) in the traditional italian ripened cheese. Other types of cheese like cottage, has shown a much lower prevalence (12.9\%) (Singh and Prakash, 2008). No sample tested positive at the PCR for Stapylococcus aureus.

\section{CONCLUSIONS}

Our study shows that traditionally obtained telemea cheese has a higher prevalence for $E$. coli and Staphylococcus. This higher load may be due to the particular processing but also to lack of strict hygiene conditions during processing. We recommend a better monitoring of the good manufacturing practices and (GMP) and good hygiene practices (GHP) within this particular processing chain.

\section{ACKNOWLEDGMENT}

This paper was published under the frame of the Applied Research Collaborative Projects, PCCA no. $153 / 2014$.

\section{REFERENCES}

1. Commission Regulation (EC) No $1441 / 2007$ of 5 December 2007 amending Regulation (EC) No 2073/2005 on microbiological criteria for foodstuffs.

2. De Buyser ML, Dufour B, Marre M, Lafarge V (2001). Implication of milk and milk products in food-borne diseases in France and in different industrialized countries. Int. J. Food Microbiol 67: 1-17.

3. Donnelly CW (2004). In Fox P, McSweeney P, Cogan $\mathrm{T}$, Guinee $\mathrm{T}$ (Ed) Cheese: Chemistry, Physics and Microbiology, Vol. 1 (pp 541-559) Academic Press, Hardbound.

4. Duminică GC (2009). Cercetări privind calitatea şi igiena brânzei telemea, Teză de doctorat, Facultatea de Medicină Veterinară Iaşi

5. FDA (2001). NCIMS HACCP Pilot Program Phase II Expansion. Retrieved February 20.2003, http://www. inspection.gc.ca/english/ppc/psps/haccp/haccpe. shtml. Fox F., Guinee P., Cogan M., McSweeney H., 2000. Fundamentals of cheese science. MD: Aspen Publ. Gaithersburg.

6. Gandra E, Fernandez M, Silva J, da Silva W (2011). Standardization of a multiplex PCR for the identification of coagulase-positive Staphylococcus. Ciên Tecnol Ali 31, 946-949.

7. Hill R (2000). Welcome to our cheese site. Retrieved October 10.2002, http://www.foodsci. uoguelph.ca/ cheese/welcom.htm.

8. Ito K (1974). Microbiological critical control points in canned foods. Food Technol. 28: 46-48.

9. Malorny B, Paccassoni E, Fach P, Bunge C, Martin A, Helmuth R (2004). Diagnostic real-time PCR for detection of Salmonella in food. Applied and Environmental Microbiology 70:7046-7052.

10. Mojsova S, Jankuloski D, Sekulovski P, Angelovski L, Ratkova M, Prodanov M (2013). Microbiological properties and chemical composition of Macedonian traditional white brined cheese, Mac Vet Rev 36(1): 13-18. 
11. Regulation (EC) no.2073/2005 regarding the microbiological creiteria for food products modified by Regulation (EC) no. 1441/2007.

12. Sandrou DK, Arvanitoyannis IS (2000). Low-fat/calorie foods: current state and perspectives. Crit Rev Food Sci Nutr 40(5):427-47.

13. Singh P, Prakash A (2008). Isolation of Escherichia coli, Staphylococcus aureus and Listeria monocytogenes from milk products sold under market conditions at agraregion. Acta agriculturae Slovenica 92(1): 83-88.

14. Soomro AH, Masud T, Anwaar K (2002). Role of lactic acid bacteria (LAB) in food preservation and human health - a review. Pakistan J Nutr 1:20-24.
15. Suler A, Popa D, Popa R, Nicolae C, Maftei M (2010). Researches regarding microbiological parameters values of telemea cheese, Scientific Papers: Aminal science and biotechnologies: 43 .

16. Temelli S, Anar S, Sen C, Akyuva P (2006). Determination of microbiologica contamination sources during Turkish white cheese production. Food Control 17: 856-861.

17. Tranter HS (1990). Food borne illness. Food borne staphylococcal illness. Lancet 336: 1044- 1046.

18. Zottola EA, Smith LB (1991) Pathogens in cheese. Food Microbiology 8:171-182. 